\title{
An Analysis of the Impact Exerted on Bearing Capacity of Pier and Pile after Increasing Pile Cap Height
}

\author{
Xianbin Huang $\mathbb{D},{ }^{1,2}$ Chenyang Liu, ${ }^{1}$ Song Hou, ${ }^{1}$ Chunyang Chen, \\ Yahong Wangren, ${ }^{1}$ and Jialin $\mathrm{Xu}^{1}$ \\ ${ }^{1}$ College of Civil Engineering, Sichuan Agricultural University, Dujiangyan 611830, Sichuan, China \\ ${ }^{2}$ Sichuan Higher Education Engineering Research Center for Disaster Prevention and Mitigation of Village Construction, \\ Dujiangyan 611830, Sichuan, China \\ Correspondence should be addressed to Xianbin Huang; hxianbin@sicau.edu.cn
}

Received 10 February 2018; Accepted 23 April 2018; Published 25 June 2018

Academic Editor: Chao Tao

Copyright (c) 2018 Xianbin Huang et al. This is an open access article distributed under the Creative Commons Attribution License, which permits unrestricted use, distribution, and reproduction in any medium, provided the original work is properly cited.

\begin{abstract}
An analysis was carried out in this paper on the bearing capacity of pier pile and seismic performance rule when the low-pile cap is increased by 1 meter, 2 meters, and 3 meters. The bottom of the pile cap of pier no. 11 of Minjiang River bridge faces three "lows": 7.6 meters lower than island, 4.6 meters lower than natural river bed, and 6.5 meters lower than low water level. The numerical simulation method is adopted to input three seismic waves of Wolong, Bajiao, and EL to evaluate the bearing capacity of pier and pile under strong earthquakes. Using the standard formula and numerical simulation method, it is observed that the bending moment and axial force of bridge pier show an insignificant change under different seismic waves when the pile cap is increased by 0-3 meters. With peak ground acceleration increased to $0.35 \mathrm{~g}$, the vertical bearing capacity and flexural capacity of pier and pile gratify the requirements; however, the pile foundation will be subject to compression and bending damage.
\end{abstract}

\section{Introduction}

1.1. Construction Site and Geology. Serving as an important tie for both shores of Minjiang River, the Minjiang arch bridge built in the 1980s can no longer meet traffic volume at this stage and needs to be demolished and rebuilt. The new Minjiang River bridge lies in the upper reach of the old bridge and is 1 meter away from the old bridge. The new bridge span features a combination of $(2 * 30)$ simply supported Tbeam plus $(40+2 * 70+40 \mathrm{~m})$ continuous box girder plus $(3 * 30 \mathrm{~m})$ simply supported T-beam plus $(40+2 \times 70+40 \mathrm{~m})$ continuous box girder plus $(40+2 \times 70+40 \mathrm{~m})$ plus $(5 * 30)$ simply supported T-beam plus $(30+2 \times 42+2 \times 30 \mathrm{~m})$ castin-place continuous box beam. The bridge stretches a total of 1175.5 meters with its width being 34 meters [1]. See Figure 1 for the diagram of the main span of Minjiang bridge. The main span of Minjiang River bridge uses continuous rigid frame of no. 10, no. 11, and no. 12 main pier, among which no. 11 pier sits in the center of the river which is greatly affected by water flow.
The main pier is characterized by a solid cross section pier body, where the middle part towards water flow direction is a rectangular section with both ends forming an arc of $146 \mathrm{~cm}$ radius. The maximum length along water flow direction is $1300 \mathrm{~cm}$. The width of traveling direction is $220 \mathrm{~cm}$ and pier height is 23.5 meters. In addition to this, pile cap volume is 14 meters $* 8$ meters $* 3.5$ meters and cap concrete volume is $392 \mathrm{~m} 3$. There are 6 pile foundations in water that are end-bearing piles which have a length of 24 meters and a diameter of $200 \mathrm{~cm}$. The vast majority of piles are embedded in moderately weathered silty mudstone. The concrete uses continuous rigid frame C55. The pier body is C40. The pier cap and tie beam adopt $\mathrm{C} 30$. And the underwater concrete used for pile foundation is C30.

As disclosed by ground investigation and drilling, site stratum is mainly the diluvium $\left(Q_{4}^{a l+p l}\right)$ and mesozoic cretaceous upper catchment group $\left(K_{2 g}\right)$. The maximum scouring depth of river bed is 2.0 meters. The thickness of pebbles in the upper layer of the river is small. The pebbles at pier no. 11 cover around 1.00 meter. The slightly intimate layer 


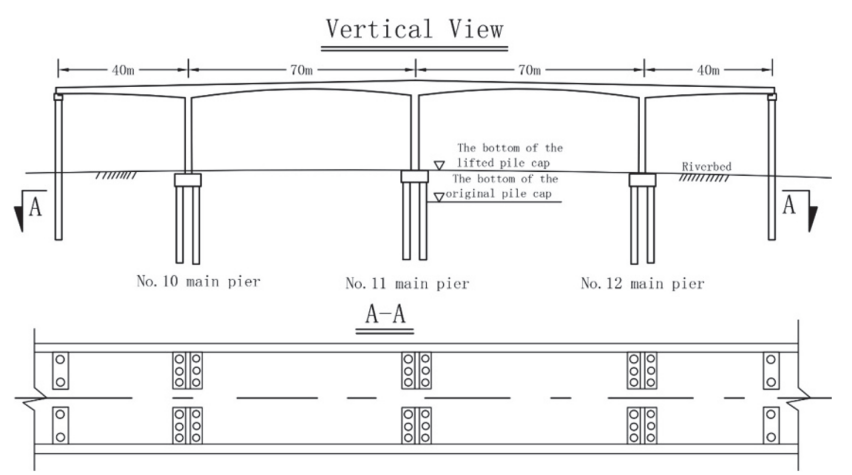

FIGURE 1: The schematic diagram of the main span of Minjiang no. 1 bridge.

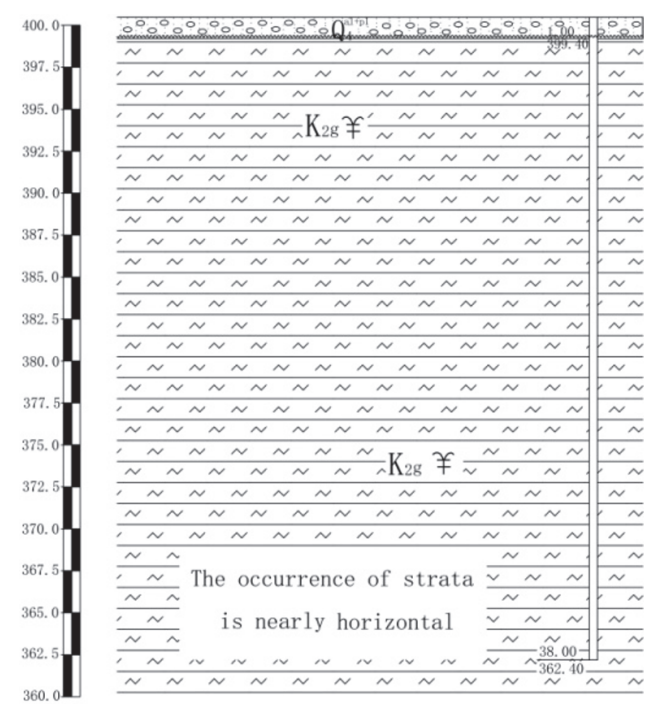

FIGURE 2: Geological section of borehole MJZK09.

is strong-weathering silty mudstone which has a thickness of 8.5 meters. The lower layer is a moderately weathered silty mudstone featuring hard rock and great thickness. The medium-density layer enjoys high bearing capacity and stable layer, which can be used as a bearing layer for bearing pile. See Figure 2 for geological section of no. 11 pier.

1.2. The Background of the Increase of Pile Cap. The ground elevation of no. 11 pier is measured as 400.40 meters by design unit. The pile foundation uses sand gravel to build island with height being 3 meters. After island construction, the construction unit measured ground elevation as 403.425 meters. The highest water level measured by construction unit during winter dry season 2016 was 402.321 meters. The bottom of pile cap of no. 11 pier was 7.604 meters lower than island, 4.579 meters lower than the surface of natural river bed, and 6.5 meters lower than low water level.

As the construction for pile cap of no. 1 pier involves difficulty and complexity, the general idea is to perform construction at a dry area. The supervision unit proposed three plans of "Large Cofferdam ABC". This can be used to channel mainstream water flow of river based on cofferdam regulation. It is suggested to use Plan 8; see Figure 3 for details. Plan A is to divide the river into a half of cofferdam and a half of water, in which construction is conducted in the cofferdam and water flows in the other half of the river alternatively. Plan B is to enclose no. 10 , no. 11 , and no. 12 pier and build island. And pile cap construction is undertaken within island. The two sides adopt trestle. Plan C uses a few cofferdams connected through trestle, where pile cap is built inside cofferdam.

Given that large cofferdam is costly and time-consuming, the construction unit used the plan of "small cofferdam and steel-pipe trestle", which is to build island within small cofferdam and embed steel sheet pile within 1-2 meters outside no. 11 pier for water plugging and drain out water from cofferdam of steel sheet pile and conduct pile cap construction. See Figure 4 for details.

In view of water environment at no. 11 pier and complexity of steel-pipe pile, a formidable difficulty was encountered at early stage using the plan of "small cofferdam plus steel-pipe pile trestle". It is easy to penetrate steel sheet pile into alluvial gravel coating layer and partially penetrate into intermediate strong-weathered silty mudstone-the depth in rock is 3 meters on average. However, it would become difficult to penetrate steel sheet pile if the depth exceeds 3 meters. The steel sheet pile has poor stability and its upper part is subject to water leak and lower part is affected by displacement. Hence, there is a need to grout the outside of steel sheet pile to consolidate soil. This takes huge time and cost; see Figures 4 and 5. Although steel sheet pile is embedded and grouted to consolidate soil, the construction for pile cap of no. 11 pier still faces many difficulties and cannot be moved forward. This is because the bottom of pile cap is 7.604 meters lower than island ground and 6.5 meters lower than low water level. It undoubtedly squeezes project schedule to complete pile foundation and pier stud under flood level between late 2016 and May 2017.

At a desperate time, the construction unit proposed to entirely increase pile cap of no. 11 pier by 3 meters and reserve 3 -meter length for rebar and concrete pile foundation at preliminary stage of pile foundation construction, namely, increase the length of pile foundation from 24 meters to 27 meters. If approved by design unit, the construction unit would directly perform pile cap construction based on 27meter pile foundation. The project undertaker asked the design unit to verify the increase of pile cap and the design unit finally agreed to increase pile cap by 2.5 meters. On the basis of the original design, the pile cap of no. 1 pier is lifted by 2.5 meters, the pile foundation is increased by 2.5 meters, and pier stud is shortened by 2.5 meters. The reinforcement of pier stud and pile foundation is increased or decreased as per original design length. The sectional dimension and pile cap size, reinforcement, and concrete grade remain unchanged. With pile cap increased by 2.5 meters, the bottom of pile cap is 2.079 meters lower than original design ground and 5.104 meters lower than island ground. The top of pile cap is 1.421 meters higher than original design ground and 1.604 meters lower than island ground; see Figures 6 and 7. The increased pile cap is also attached to intermediate strong-weathering 

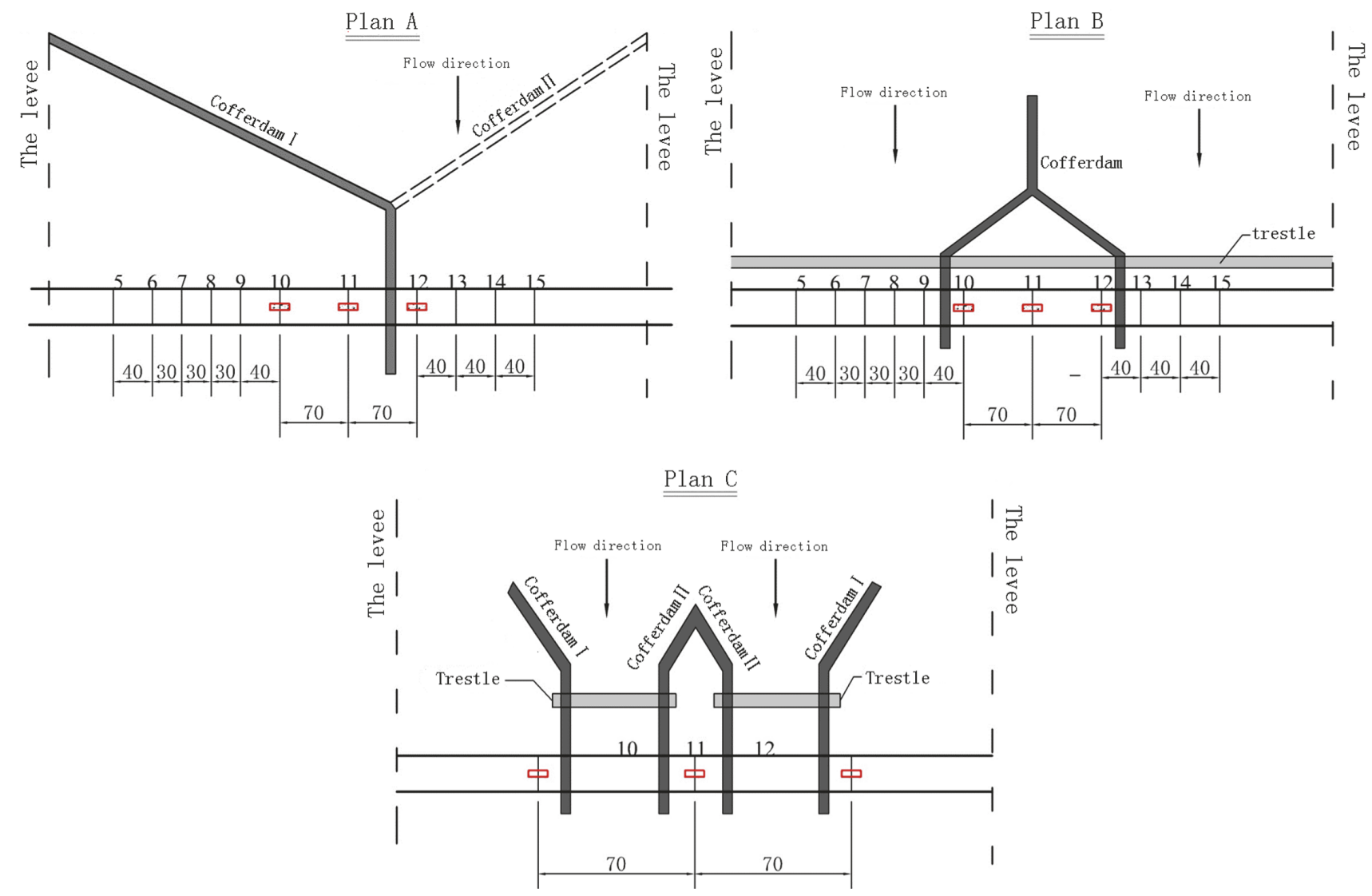

FIgURE 3: No. 10, no. 11, and no. 12 pile foundation and cofferdam construction for Cofferdam ABC program.
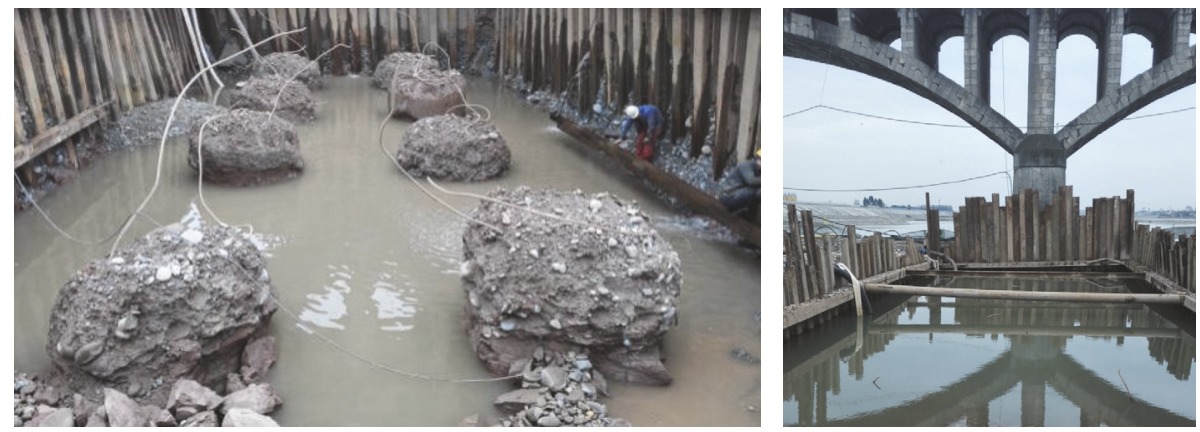

FIgURE 4: The photo of no. 11 pier cap plate pile cofferdam.

silty mudstone, belonging to low-pile cap. The increase of pile cap falls under special change-the design drawing is changed and engineering cost remains unchanged.

1.3. Related Research on High Pile Cap and Low-Pile Cap. According to the zoning map [2], the peak acceleration of ground motion in Meishan City is $0.1 \mathrm{~g}$, and the characteristic period of seismic response spectrum is $0.45 \mathrm{~s}$, corresponding to the basic earthquake intensity of VII degree. The area was influenced by both Wenchuan earthquake in 2008 and the Lushan earthquake in 2013. Meishan City is $121 \mathrm{~km}$ away from the epicenter of the Wenchuan M8 earthquake and is located at a distance of $84 \mathrm{~km}$ from the epicenter of the Lushan earthquake, shown in Figure 8.

Tang et al. [3] carried out vibration platform tests on the seismic interaction of pile-soil-beam structures on liquefiable high-rise pile caps. The free length of high pile foundations can easily cause pile damage under large earthquakes. Huang et al. [4] analyzed the effect of the height change of high pile caps on the seismic performance of the bridge piers. Nie et al. [5] thought the train-induced vertical dynamic loads on pile caps increase with the total span length. Chen et al. [6] studied the influence of pile cap effect on piled embankment supporting high-speed railway. Six prestressed high strength 


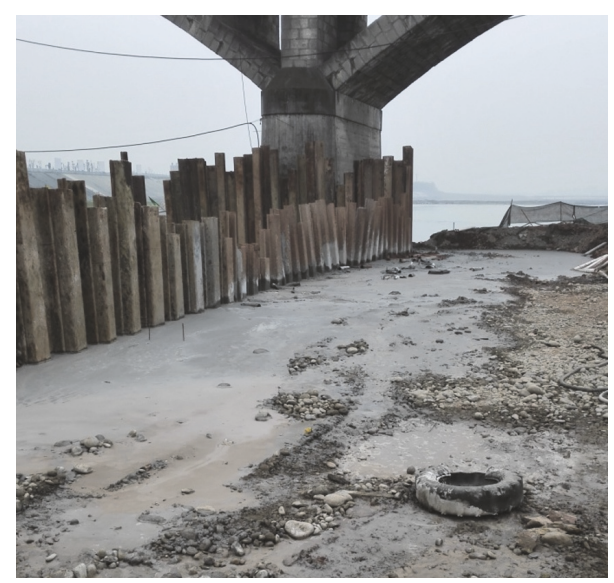

FIGURE 5: The photo of no. 11 pier-pile platform steel sheet pile cofferdam soil reinforcement grouting.

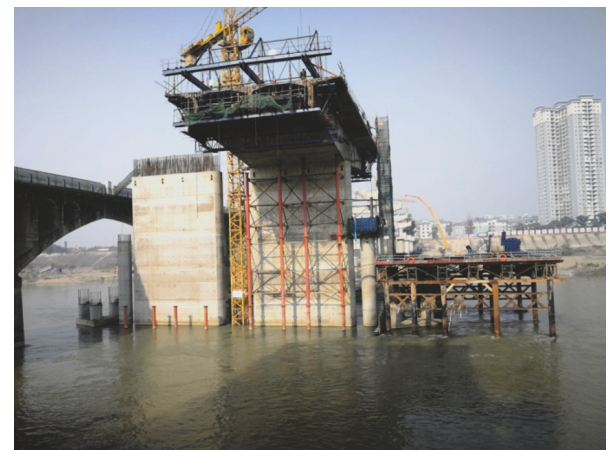

FIgURE 6: The photo of no. 11 pier after the completion.

concrete (PHC) pile-to-pile cap connections were tested to evaluate their damage process and failure modes under low cyclic loading [7]. The static lateral behavior of a battered pile group foundation was investigated using three-dimensional finite element (FE) analysis [8]. Taha et al. [9] studied the seismic pile-soil-geosynthetic interaction of geosyntheticreinforced pile foundations.

Zhenfeng et al. [10] analyzed the seismic performance of a high-rise pile cap foundation with riverbed scour; a finite element model for foundations is introduced in the OpenSees finite element framework. Chen et al. [11] showed that the pile group with elevated cap is widely used as foundation of offshore structures. Lang et al. [12] showed that the procedure was carried out for a new high-rise cap-pile group foundation adapted to the loading characteristics of offshore wind turbines. Elevated pile cap foundation is one of the most popular foundation types for offshore wind turbines. Wang et al. [13] evaluated the ground, pile foundation, and overall bridge seismic response. Lang et al. [14] investigated the dynamic behavior of a reinforced-concrete (RC) elevated cap-pile foundation during (and prior to) soil liquefaction. Wang et al. [15] showed that a displacement ductility capacity of 3.5 is observed for the elevated pile cap foundation. High pile caps are more vulnerable to destruction in strong earthquakes, and there are many domestic and foreign researches. As a
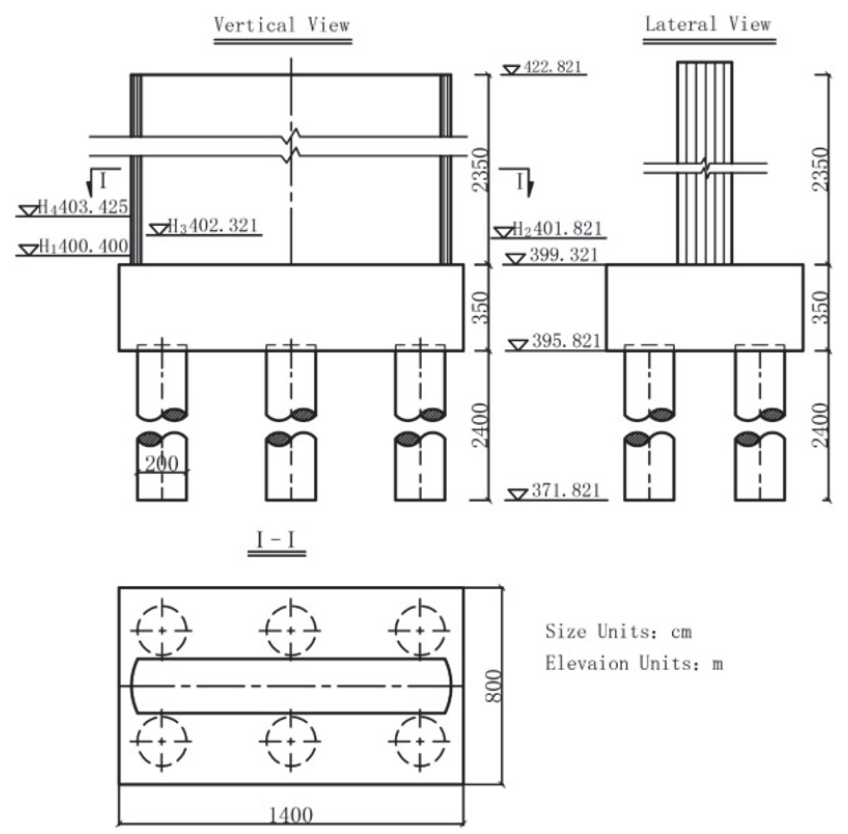

Note

H1-Ground elevation for No. 11 pier

$\mathrm{H} 2$-Elevation after the top of pile cap increased by $2.5 \mathrm{~m}$

H3-the highest water level in low water season of winter 2016.

H4-Ground elevation after building island

FIGURE 7: No. 11 pier, pile layout and the main dimensions of the diagram.

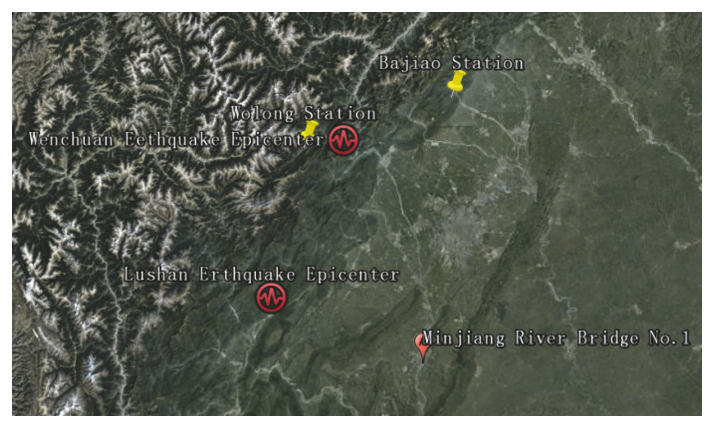

FIGURE 8: The relative position of Minjiang no. 1 Bridge and surrounding strong earthquake station and epicenter of the powerful earthquake.

common structural form of the bridges, low-pile caps mostly focus on static force analysis. Zhang [16] conducted a pseudostatic test on the foundation of low-pile caps. Under the condition of applying horizontal loads to the caps, the maximum bending moment of the pile appears at the pile heads. shake-table experiments were conducted to investigate the behavior of a reinforced-concrete (RC) low-cap-pile group embedded in liquefiable soils [17, 18]. Tang et al. [19] carried out a shake-table experiment to investigate the behavior of a reinforced-concrete low-cap-pile group embedded in this type of ground. There are many studies on the response of the platform under strong earthquakes $[20,21]$. The dynamic 
TABLE 1: Natural vibration period and vibration mode of Shougang Bridge before and after cap rise cap.

\begin{tabular}{|c|c|c|c|c|c|c|c|c|}
\hline \multirow{2}{*}{$\begin{array}{l}\text { Modal } \\
\text { number }\end{array}$} & \multicolumn{2}{|c|}{ Raise $0 \mathrm{~m}$} & \multicolumn{2}{|c|}{ Raise $1 \mathrm{~m}$} & \multicolumn{2}{|c|}{ Raise $2 \mathrm{~m}$} & \multicolumn{2}{|c|}{ Raise $3 \mathrm{~m}$} \\
\hline & $\begin{array}{c}\text { Natural } \\
\text { period }\end{array}$ & $\begin{array}{l}\text { Mode shape } \\
\text { description }\end{array}$ & $\begin{array}{c}\text { Natural } \\
\text { period }\end{array}$ & $\begin{array}{l}\text { Mode shape } \\
\text { description }\end{array}$ & $\begin{array}{c}\text { Natural } \\
\text { period }\end{array}$ & $\begin{array}{l}\text { Mode shape } \\
\text { description }\end{array}$ & $\begin{array}{l}\text { Natural } \\
\text { period }\end{array}$ & $\begin{array}{l}\text { Mode shape } \\
\text { description }\end{array}$ \\
\hline 1 & 2.184 & Along-bridge & 2.123 & Along-bridge & 2.05 & Along-bridge & 1.898 & Along-bridge \\
\hline 2 & 0.809 & Across-bridge & 0.858 & Across-bridge & 0.855 & Across-bridge & 0.775 & Across-bridge \\
\hline 3 & 0.161 & Vertical torsion & 0.168 & Vertical torsion & 0.175 & Vertical torsion & 0.178 & Vertical torsion \\
\hline 4 & 0.147 & Vertical torsion & 0.15 & Vertical torsion & 0.151 & Vertical torsion & 0.143 & Vertical torsion \\
\hline 5 & 0.075 & Along-bridge & 0.081 & Along-bridge & 0.088 & Along-bridge & 0.076 & Along-bridge \\
\hline 6 & 0.072 & Vertical torsion & 0.071 & Vertical torsion & 0.07 & Vertical torsion & 0.065 & Vertical torsion \\
\hline 7 & 0.035 & Vertical torsion & 0.035 & Vertical torsion & 0.035 & Vertical torsion & 0.034 & Vertical torsion \\
\hline
\end{tabular}

analysis of the low-pile bearing platform is less reported, especially for the corresponding bearing capacity and seismic performance of the low-pile bearing platform under the seismic response recurring from the Wenchuan earthquake. In this paper, based on newly built Minjiang-Yiqiao, a partial pier-pile cap-pile model was established to conduct a seismic response analysis to study the bearing capacity and seismic performance of low pier piles in the Wenchuan earthquake and analyze the chained effects of the appropriate lifting of the low-pile caps on the construction.

\section{Establishing No. 11 Pier-Pile Finite Element Model}

2.1. Bridge Finite Element Model. The Midas/Civil software is used to establish the finite element model for the seismic response of pier-pile cap piles of no. 11 Minjiang-Yiqiao Bridge. The structure adopts space beam and rod units. The model has a total of 6 piles with each length at $24 \mathrm{~m}$ and the diameter at $2 \mathrm{~m}$, and the height of the pier is $23.5 \mathrm{~m}$. The model totals 64 units and 74 nodes. The upper load is exerted on the top of the pier by the forces. The soil-structure interaction is taken into consideration in the pile foundation. The soil spring stiffness is established based on the actual soil layer information. The pile-soil knot model before the pile cap lifting is built considering the soil elasticity. The pile-soil knot model after the rise of the pile cap at $1 \mathrm{~m}, 2 \mathrm{~m}$, and $3 \mathrm{~m}$ is also established [22]. The finite element model of the bridge piers, caps, and piles before pier no. 11 is lifted is shown in Figure 9. The seismic responses of the no. 11 abutment and the pile foundation under the Wenchuan earthquake simulation and the EL wave were analyzed comparatively in which data of Wolong and the Bajiao seismic waves were both taken from the 2008 Wenchuan Magnitude-8 Earthquake in 2008.

2.2. Bridge Vibration Characteristics. Using the modal analysis of the soil knot model, the self-vibration period and mode of no. 11 pier pile before and after the lifting of the bearing platform are obtained, as shown in Table 1 . The analysis results can provide data for the calculation of stiffness and quality factors in the nonlinear seismic response analysis. In Table 2, it can be seen that the height of the bearing platform is increased by $0 \mathrm{~m}, 1 \mathrm{~m}, 2 \mathrm{~m}$, and $3 \mathrm{~m}$, respectively, and the

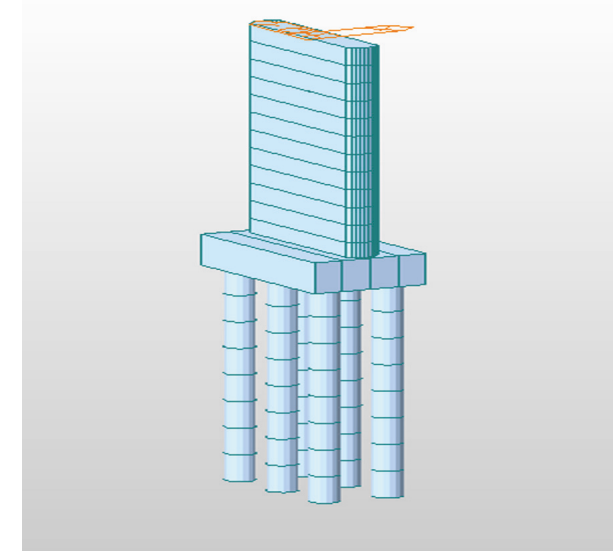

FIGURE 9: Finite element model before no. 11 rise for pier foundation.

TABLE 2: Pier no. 11, inputs of the corresponding maximum seismic acceleration of the earth's surface/gal.

\begin{tabular}{lccc}
\hline Seismic waves & East - west & North-south & Vertical \\
\hline EL Seismic waves & 348.880 & 209.913 & 241.864 \\
Wolong Seismic waves & 956.724 & 662.186 & 947.137 \\
Bajiao Seismic waves & 581.592 & 556.169 & 633.923 \\
\hline
\end{tabular}

period of the self-vibration of the model structure was slightly decreasing, and the structural mode did not change.

2.3. Bearing Capacity Analysis of Pier Pile under Strong Seismic Effect on Bridge. Based on the work of Huang et al. [23], the earthquake response analysis is carried out on MinjiangYiqiao before and after the rise of its pile cap through inputting the data from the Wolong, Bajiao, and EL seismic waves, with ground motion response spectrum shown in Figure 10 and data in Table 2.

Under the effect of the Wolong and the Bajiao seismic waves, the displacement of the pier top before and after lift of the bearing platform is not significant. In the strong seismic response, the displacement of the top of the pier before and after the lifting of the platform is more subject to the Bajiao seismic wave with the maximum displacement at $20 \mathrm{~cm}$, which can easily cause the damage of the main beam 


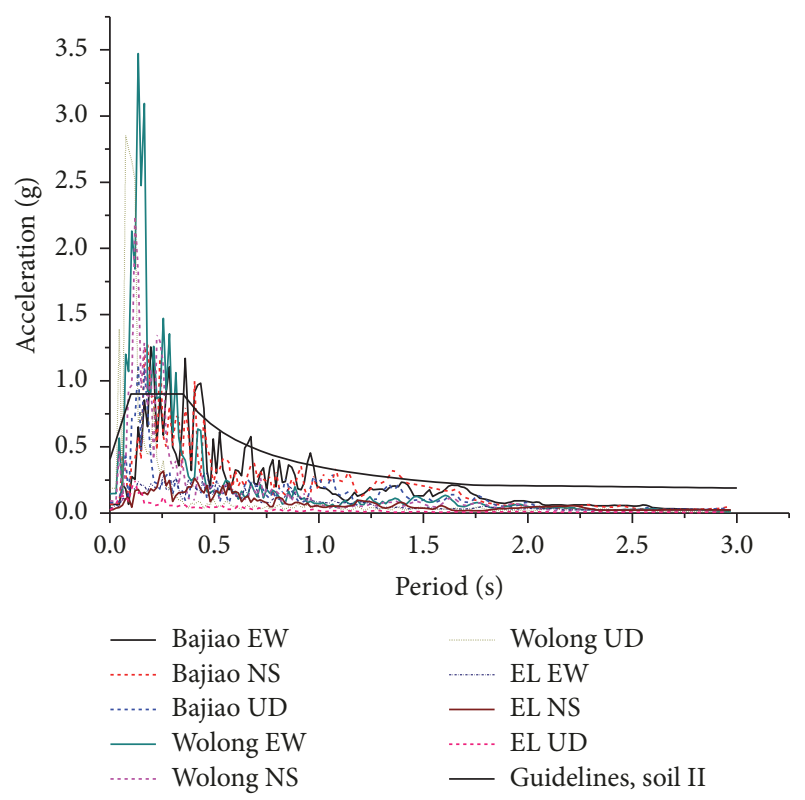

FIGURE 10: Ground motion response spectrum.

TABle 3: Pier no. 11, the maximum displacement of the pier top before and after pier lifting/cm.

\begin{tabular}{lcccc}
\hline \multirow{2}{*}{ Seismic waves } & \multicolumn{4}{c}{$\begin{array}{c}\text { Height of pile cap lift } \\
(\mathrm{m})\end{array}$} \\
& $0 \mathrm{~m}$ & $1 \mathrm{~m}$ & $2 \mathrm{~m}$ & $3 \mathrm{~m}$ \\
\hline EL Seismic waves & 2.4 & 2.2 & 2.1 & 1.7 \\
Bajiao waves & 20 & 19.5 & 19.4 & 19.9 \\
Wolong seismic wave & 15.2 & 15.8 & 15.8 & 14.5 \\
\hline
\end{tabular}

and the collision of the beams. Under the EL wave with lower acceleration of the earthquake, the displacement of the pier top decreases as the height of the bearing platform increases, as shown in Table 3.

It can be seen from Figures 11, 12, 13, and 14 that there is no significant change in the force of the pier under the same seismic wave before and after the platform is slightly raised, which has little effect on the seismic performance.

The bending moment of the pile top is significantly affected by the Bajiao seismic wave before and after the platform cap is lifted, reaching $14274.9 \mathrm{kN} \cdot \mathrm{m}$; with the elevation of the platform, the bending moment showed a slight decrease at first and then slightly decreased. The bending moment of the pile top demonstrated a slight increase as the pile cap increases when the pile foundation is under the influence of the Wolong seismic wave (see Figure 11). The bending moment of the pier bottom is most affected by the Bajiao seismic wave, with a maximum of $79,5321.7 \mathrm{kN} \cdot \mathrm{m}$. The same seismic wave had less effect on the bending moment of the pier bottom with the rise of the bearing platform, as shown in Figure 12. The axial force of the bridge pier is most affected by the Wolong wave, with the maximum value of $126199.9 \mathrm{kN}$. The Wolong wave decreases slightly with the increase of the height of the pile cap first, and the Bajiao wave

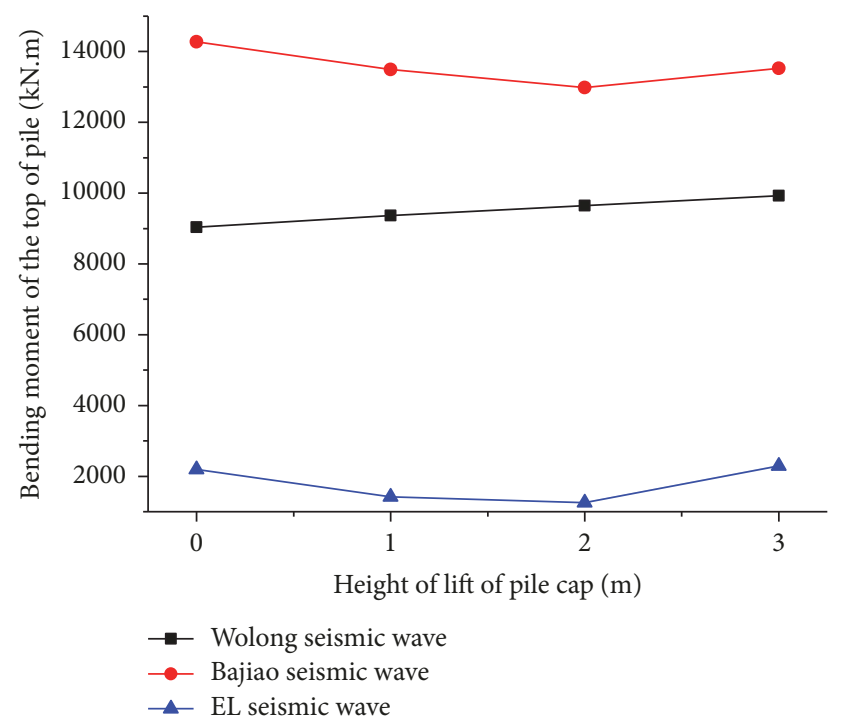

FIGURE 11: Bending moment of the top of pile before and after the lifting of pile cap.

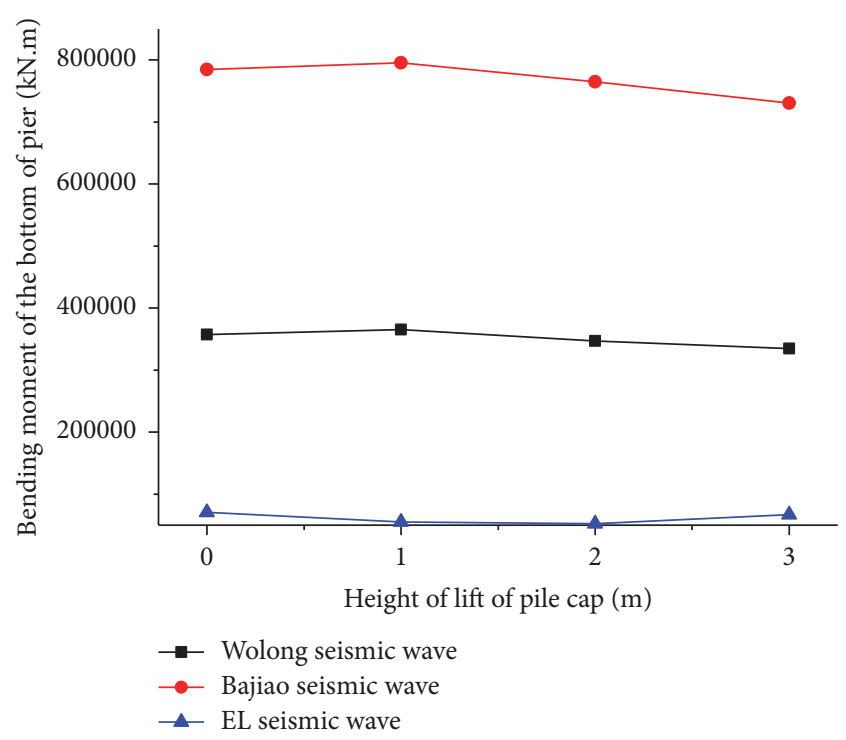

FIGURE 12: The bending moment of pier bottom at transverse direction of bridge before and after cap rise.

shows a linear decrease with the slight increase of the pile cap. Under the effect of the EL seismic wave, the axial force of the bridge piers gradually decreases as the height of the bearing platform increases, as shown in Figure 13.

\section{Checking Calculation of Pier-Pile Carrying Capacity}

3.1. Check Calculation of Pier Bearing Capacity. The compressive bearing capacity of pier no. 11 was $409291.2 \mathrm{kN}$, calculated according to the standard [24]. Through Midas's analysis of pier no. 11, the actual maximum axial force under the effect of Wolong wave is $126199.9 \mathrm{kN}$. The designed compressive bearing capacity is much larger than the actual 


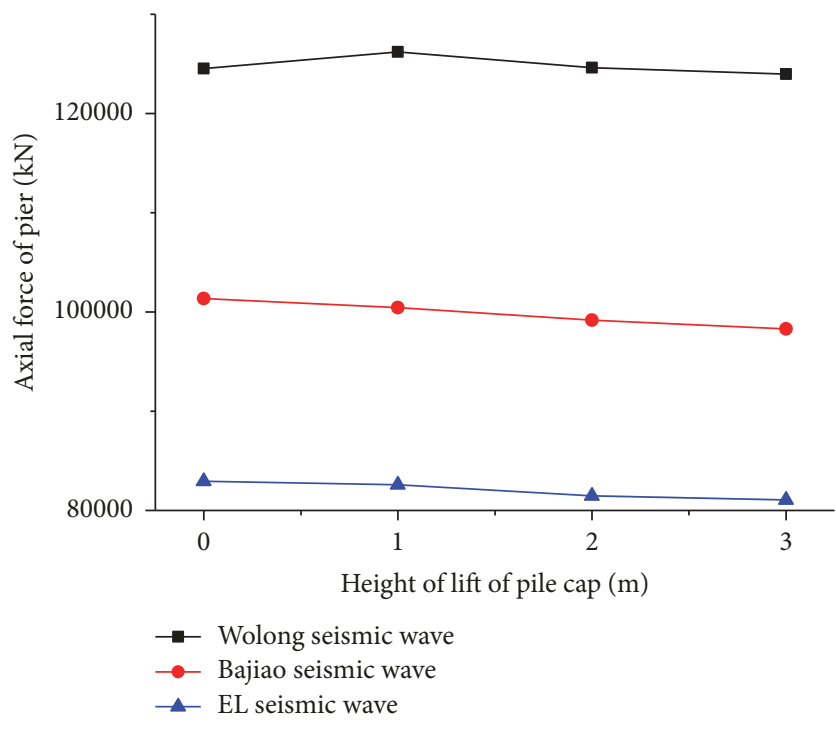

Figure 13: Axial force of pier before and after pile cap rise.

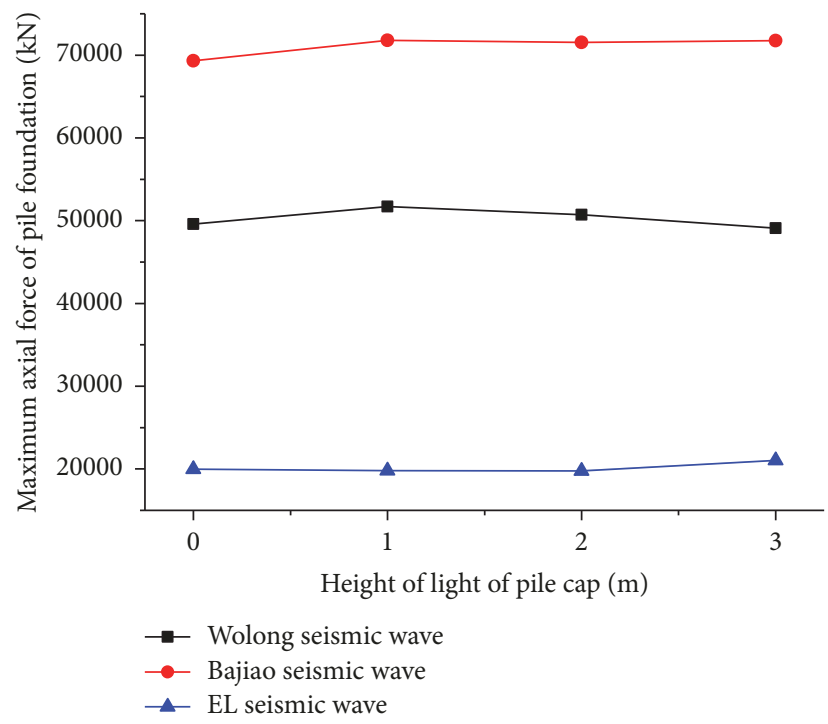

Figure 14: Axial force of pile foundation before and after pile cap rise.

maximum axial force, which means that the compressive bearing capacity is strong enough and safe under strong earthquakes.

The Bajiao wave has the greatest influence on the bending moment of no. 11 pier column. After the platform was lifted, no. 11 pier column was found to have a yield bending moment of $52,529,900,905 \mathrm{kN} \cdot \mathrm{m}$ according to Midas's bending moment curvature, while no. 11 pier column is actually subject to a bending moment of $79,5321.7 \mathrm{kN} \cdot \mathrm{m}$ in a strong earthquake, and the designed yield moment is very large. The design adopts large-sized solid piers with large safety factor and the columns are open to optimization.

The analysis shows that, under the action of the three seismic waves, the compressive and flexural bearing capacity of pier no. 11 before and after the lifting of the pile cap are sufficiently large and safe.

According to the standard [25], the vertical bearing capacity of the pile foundation is calculated to be $37428.8 \mathrm{kN}$. The actual vertical load of no. 11 pier-pile foundation under the EL wave is $21023.5 \mathrm{kN}$, and the pile foundation is safe. The actual vertical loads under the Wolong wave and the Bajiao wave are $50704.9 \mathrm{kN}$ and $71778.6 \mathrm{kN}$, respectively. The vertical bearing capacity of the pile foundation is insufficient (see Figure 14).

According to the standard [26], the horizontal antishear capacity of the pile foundation is calculated to be $15434 \mathrm{kN}$. The actual antishear force of the pile foundation calculated by Civil is $6478 \mathrm{kN}$. The antishear capacity of no. 11 pier-pile foundation meets the requirements.

Before and after lifting of the bearing platform, the maximum bending moment of the pile subjected to the EL wave is $2131.1 \mathrm{kN} \cdot \mathrm{m}$, which is less than the yield moment of the pile foundation as $7669.5 \mathrm{kN} \cdot \mathrm{m}$. The pile foundation of pier no. 11 is safe in the EL wave. The maximum bending moments of the pile foundation in the seismic waves at Wolong and Bajiao are $9647.7 \mathrm{kN} \cdot \mathrm{m}$ and $14274.9 \mathrm{kN} \cdot \mathrm{m}$, both of which are greater than the yield moment $7669.5 \mathrm{kN} \cdot \mathrm{m}$. The no. 11 pierpile foundation will undergo bending failure at its top.

In summary, the antishear capacity of the pile foundation meets the requirements before and after the lifting of the bearing platform, and the vertical bearing and bending capacity of the pile foundation meet the requirements for the EL seismic wave. Before and after the platform was lifted, the vertical bearing capacity of pile no. 11 was damaged by pressure, and the top of the pile was subject to bending damage under the influence of Wolong and Bajiao seismic waves.

According to the zoning map [2], the peak acceleration of ground motion in Meishan City is $0.1 \mathrm{~g}$, and the basic earthquake intensity is VII degree. Under this condition, pier no. 11 of Meishan Bridge is safe. Pier no. 11 is also safe under the action of EL waves with peak earthquake acceleration of $0.35 \mathrm{~g}$ (over $0.1 \mathrm{~g}$ ). Under the action of the Wolong wave and the Bajiao seismic wave with peak earthquake acceleration of $0.50 \mathrm{~g}$ (far more than $0.1 \mathrm{~g}$ ), pier no. 11 is safe, but the corresponding pile foundation will be damaged.

\section{Conclusions}

The conclusions are drawn as follows based on the numerical analysis of pier no. 11 and the comparison of the formulas in the standard to analyze the variations of the bearing capacity of the pier piles under strong seismic forces before and after the lifting of the bearing platform (pile cap):

(a) The overall trend of bending moment and axial force under the same seismic waves of the bridge pier piles is not noticeable as the pile caps are elevated by $0 \mathrm{~m}$, $1 \mathrm{~m}, 2 \mathrm{~m}$, or $3 \mathrm{~m}$.

(b) The bending resistance and compression bearing capacity of the bridge pier meet the design requirements when the bearing platform is lifted by $3 \mathrm{~m}$, which meets the ground motion peak acceleration of $0.1 \mathrm{~g}$ in Meishan City and the basic earthquake 
intensity of VII degree in fortification requirements with a higher design safety reserve.

(c) Before and after the height of the platform rises, the peak acceleration of the earthquake is about $0.35 \mathrm{~g}$. The vertical bearing capacity and bending capacity of no. 11 pier pile meet the requirements. Under the ground peak acceleration of the earthquake greater than $0.5 \mathrm{~g}$, the vertical and bending capacity of the pier meet the requirements. However, the corresponding pile foundation will be subject to pressure and bending damage.

The slight elevation of the low-pile cap poses little effect on its load. According to the actual situation of Minjiang-Yiqiao, a moderate elevation of the pier no. 11 pile cap is conducive to construction.

\section{Data Availability}

The data used to support the findings of this study are available from the corresponding author upon request.

\section{Conflicts of Interest}

The authors declare that there are no conflicts of interest regarding the publication of this paper.

\section{Acknowledgments}

Research and Innovation Teams funded projects of Sichuan Provincial Department of Education (16TD0006), National Natural Science Foundation of China (4167020785), and National Natural Science Foundation of Youth Science Foundation (5140081608).

\section{References}

[1] Sichuan Province Transportation Department Highway Planning Survey Design And Research. Meishan Two-stage construction design drawings for reconstruction project of Minjiang River No.1 Bridge at Dongpo district, Meishan (second bridge project). Chengdu, 2016.

[2] General Administration of Quality Supervision, Inspection and Quarantine of the People's Republic of China, and Standardization Administration of the People's Republic of China, "Seismic ground motion parameters zonation map of China," Tech. Rep. GB18306-2015, General Administration of Quality Supervision, Inspection and Quarantine of the People's Republic of China, Standardization Administration of the People's Republic of China, Beijng, China, 2015.

[3] L. Tang, X.-Z. Ling, P.-J. Xu, and X. Gao, "Shaking table test for seismic interaction of pile groups-soil-bridge structure with elevated cap in liquefiable ground," Zhongguo Gonglu Xuebao/China Journal of Highway and Transport, vol. 23, no. 4, pp. 51-57, 2010

[4] X. B. Huang, S. Hou, and M. Liao, "Effects of pile caps height variety on seismic behavior of bridge pier piles," Earthquake Engingering and Engingering Dynamics, vol. 137, no. 12, pp. 154161, 2017.

[5] R. Nie, Y. F. Chen, W. Leng, and Q. Yang, "Experimental measurement of dynamic load parameters for pier pile caps of high-speed railway bridges," Proceedings of the Institution of Mechanical Engineers, Part F: Journal of Rail and Rapid Transit, vol. 231, no. 2, pp. 162-174, 2015.

[6] H. Chen, J. Ma, X. Qin, and H. Aziz, "Influence of pile cap effect on piled embankment supporting high-speed railway," Advances in Structural Engineering, vol. 16, no. 8, pp. 1447-1455, 2013.

[7] Z. Yang and W. Wang, "Experimental and numerical investigation on the behaviour of prestressed high strength concrete pileto-pile cap connections," KSCE Journal of Civil Engineering, vol. 20, no. 5, pp. 1903-1912, 2016.

[8] A. Souri, M. Abu-Farsakh, and G. Voyiadjis, "Study of static lateral behavior of battered pile group foundation at I-10 Twin Span Bridge using three-dimensional finite element modeling," Canadian Geotechnical Journal, vol. 53, no. 6, pp. 962-973, 2015.

[9] A. Taha, M. Hesham El Naggar, and A. Turan, "Experimental study on the seismic behaviour of geosynthetic-reinforced pilefoundation system," Geosynthetics International, vol. 22, no. 2, pp. 183-195, 2015.

[10] H. Zhenfeng, Y. Aijun, and F. Lichu, "Effects of riverbed scour on seismic performance of high-rise pile cap foundation," Earthquake Engineering and Engineering Vibration, vol. 9, no. 4, pp. 533-543, 2010.

[11] Y.-M. Chen, M. Gu, R.-P. Chen, L.-G. Kong, Z.-H. Zhang, and X.-C. Bian, "Behavior of pile group with elevated cap subjected to cyclic lateral loads," China Ocean Engineering, vol. 29, no. 4, pp. 565-578, 2015.

[12] R. Lang, R. Liu, J. Lian, and H. Ding, "Study on load-bearing characteristics of a new pile group foundation for an offshore wind turbine," The Scientific World Journal, vol. 2014, Article ID 394104, 2014

[13] N. Wang, A. Elgamal, and T. Shantz, "Recorded seismic response of the Samoa Channel Bridge-foundation system and adjacent downhole array," Soil Dynamics and Earthquake Engineering, vol. 92, pp. 358-376, 2017.

[14] R. Lang, R. Liu, J. Lian, and H. Ding, "Study on load-bearing characteristics of different types of pile group foundations for an offshore wind turbine," Journal of Coastal Research, pp. 533$541,2015$.

[15] X. Wang, A. Ye, Z. He, and Y. Shang, "Quasi-Static Cyclic Testing of Elevated RC Pile-Cap Foundation for Bridge Structures," Journal of Bridge Engineering, vol. 21, no. 2, Article ID 04015042, 2016.

[16] C. N. Zhang, The Application of Derivation Method in the Antiseismic Analysis for Overpass System [Master, thesis], Tongji University, Shanghai, China, 2003.

[17] L. Tang, X. Zhang, X. Ling, L. Su, and C. Liu, "Response of a pile group behind quay wall to liquefaction-induced lateral spreading: a shake-table investigation," Earthquake Engineering and Engineering Vibration, vol. 13, no. 4, pp. 741-749, 2014.

[18] M. H. Hsieh, Y. C. Wu, and W. Y. Hung, "Experimental analysis of pile group in liquefying soil under a ground motion using centrifuge test," Journal of Vibration Engineering \& Technologies, vol. 5, no. 5, pp. 423-428, 2017.

[19] L. Tang, X. Zhang, X. Ling, H. Li, and N. Ju, "Experimental and numerical investigation on the dynamic response of pile group in liquefying ground," Earthquake Engineering and Engineering Vibration, vol. 15, no. 1, pp. 103-114, 2016.

[20] X. Wang, B. Zhu, and S. Cui, "Research on Collapse Process of Cable-Stayed Bridges under Strong Seismic Excitations," Shock and Vibration, vol. 2017, Article ID 7185281, 2017. 
[21] J. Yi and J. Li, "Longitudinal Seismic Behavior of a Single-Tower Cable-Stayed Bridge Subjected to Near-Field Earthquakes," Shock and Vibration, vol. 2017, Article ID 1675982, 2017.

[22] Y. Huang, R. Li, and W. J. Zhu, "Analysis of damage mechanism of small radius curve continuous beam bridges during the Wenchuan Earthquake," Earthquake Engineering \& Engineering Dynamics, vol. 34, no. S1, pp. 383-388, 2014.

[23] X. Huang, S. Hou, M. Liao, and Z. Zhu, "Bearing capacity evaluation and reinforcement analysis of bridge piles under strong earthquake conditions," KSCE Journal of Civil Engineering, pp. 1-9, 2017.

[24] CCCC Highway Consultants CO Ltd, "Code for design of highway reinforced concrete and prestressed concrete bridges and culverts," JTG D62-2004, China Communications Press, Beijing, China, 2004.

[25] CCCC Highway Consultants CO Ltd, "Code for design of ground base and foundation of highway bridges and culverts," JTG D63-2007, China Communications Press, Beijing, China, 2007.

[26] Ministry of Horse and Urban-Rural Development of the People's Republic of China. Code for Design of Concrete Structures, GB 50010-2010, China Architecture \& Building Press, Beijing, China, 2014. 


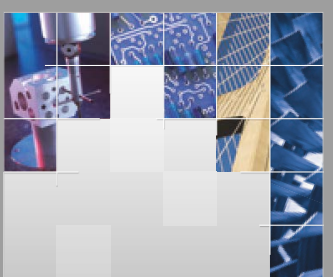

\section{Enfincering}
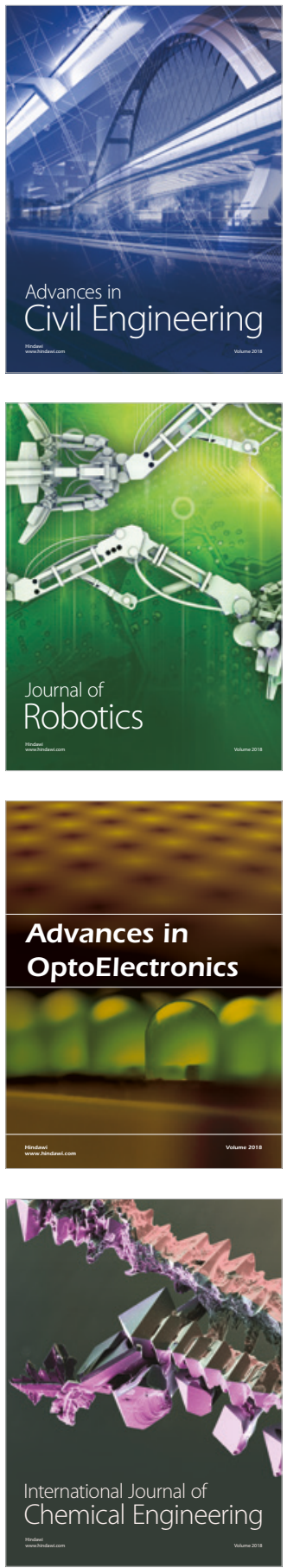

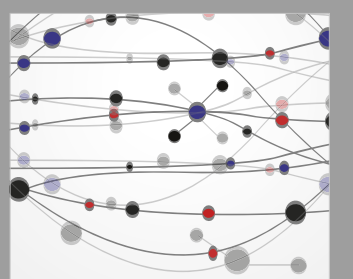

\section{Rotating \\ Machinery}

The Scientific World Journal

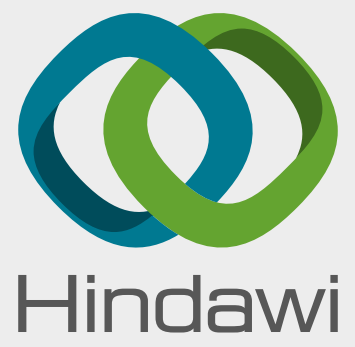

Submit your manuscripts at

www.hindawi.com
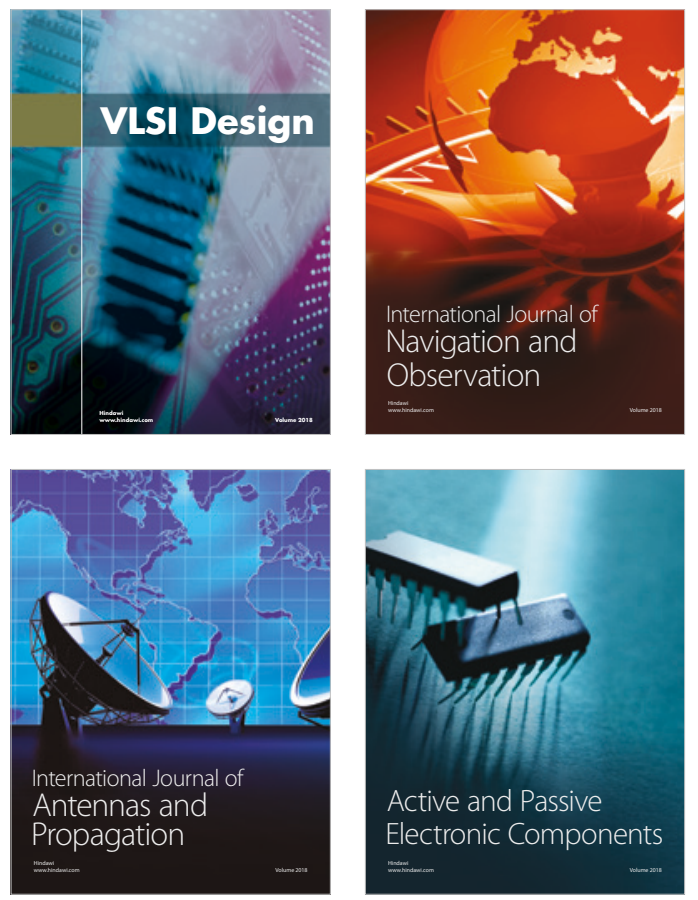
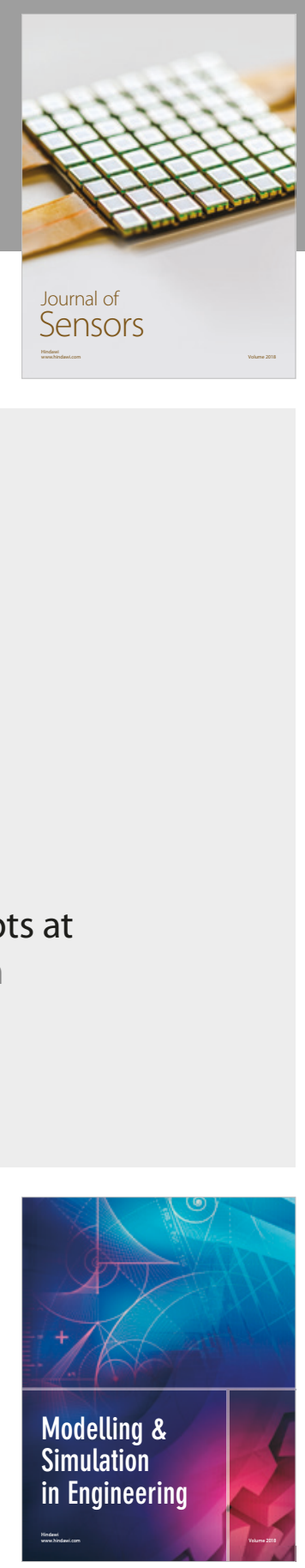

\section{Advances \\ Multimedia}
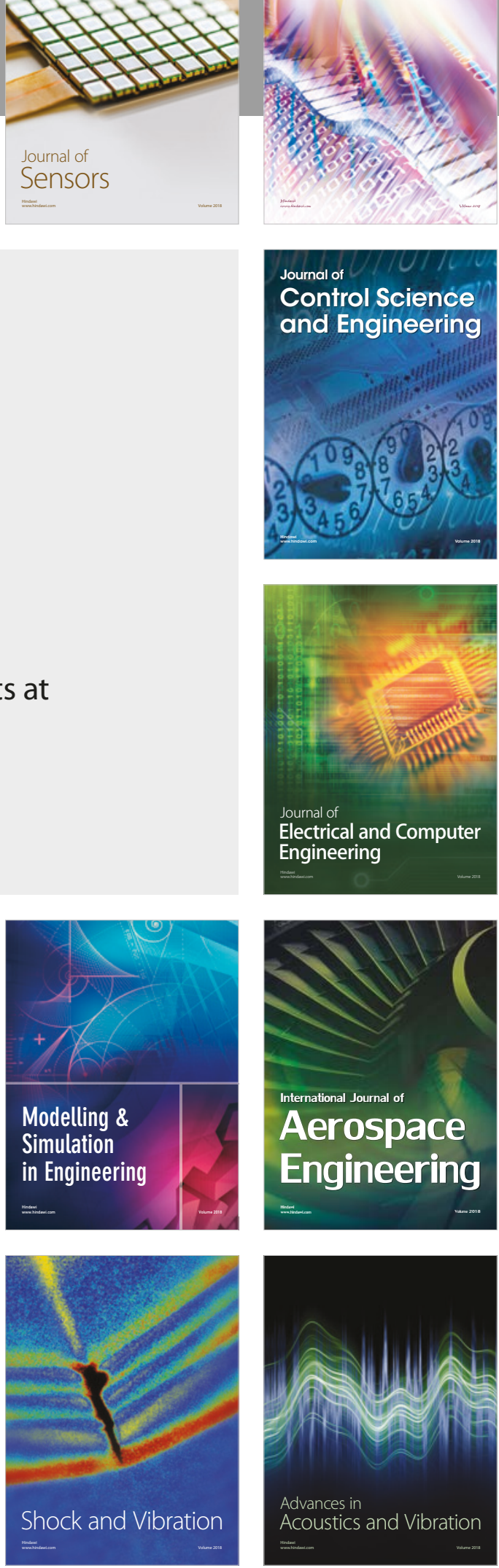